\title{
1 The Effectiveness of the European Union's Cohesion Policy in the Years 2000-2015
}

\author{
Maciej Pietrzykowski ${ }^{1}$
}

\begin{abstract}
The impact of the cohesion policy in the 2014-2020 framework is estimated to be approximately 450 billion euros. Such large intervention requires the effectiveness of high absorption and ongoing successes in achieving set goals. The aim of this paper is to examine the convergence of European Union economies at the national and regional levels (NUTS2), using the measure of unconditional convergence ( $\beta$-convergence) and Pearson Correlation. Analysis was conducted for the periods covering the two most recent EU financial perspectives. A distinction has been made between convergence in "old" (core EU-15) and "new" (EU-13) Member States. Conclusions focus on discussing the results of the analysis and recommendations to enhance EU cohesion policy directions.
\end{abstract}

Key Words: local economic development, cohesion policy, convergence, divergence

\subsection{Introduction}

Cohesion policy is one of the key investment policies in the European Union. It focuses on less developed countries and regions, supporting the process of reducing economic, social, and territorial disparities that continue to exist in the EU. As indicated by the latest (seventh) Report on Economic, Social and Territorial Cohesion, the financial crisis and following recessions stunted long-term growth in the cohesion of the European Union, which was manifested in the stratification of levels of such indicators as GDP, GDP per capita, employment rate and unemployment rate (European Commission, 2017). The subsequent progressive recovery began to reverse this unfavourable trend, but the question remains as to what extent the applied intervention instruments and adopted priorities are appropriate, whether the aid and policy instruments are correctly addressed to the beneficiaries, as well as whether we can indicate some outcomes in terms of sustainability of the policy's implementation. Taking into account national contributions and private funds, the impact of the cohesion policy in the 2014-2020 framework is estimated to be approximately 450 billion euros, which includes cohesion policy funding of around

1 Department of International Competitiveness, Poznań University of Economics and Business, 61-875 Poznan, Wielkopolska, Poland. Correspondence: maciej.pietrzykowski@ue.poznan.pl

Ә Open Access. (c) 2020 Ida Musiałkowska, Piotr Idczak, Oto Potluka and chapters' contributors. Published by De Gruyter. (c) BY-NC-ND This work is licensed under the Creative Commons Attribution-NonCommercial-NoDerivs 3.0 License. https://doi.org/10.1515/9788395720451-002 
350 billion euros. For 7 out of 28 European Union countries (including Poland) in the years 2015-2017, cohesion policy accounted for over 50\% of public investment (European Commission, 2017). Therefore, the effectiveness of cohesion policy from the point of view of overcoming development disparities is an important issue; one which for many years has been the subject of research by scientists as well as a point of reference for the actions of politicians. Examining the success as well as the territorial impact from the implementation of the EU cohesion policy requires exploring whether the convergence has taken place in European Countries and Regions and whether there is a correlation between cohesion policy assistance and GDP measures.

\subsection{Convergence in Research To-Date}

Research into the convergence of countries had already begun in the 1980s. The classic and neo-classical growth theory suggests that rich and poor regions or countries will converge as they integrate, mainly due to diminishing returns to capital. Baumol (1986), who analysed data from 16 market economies, claimed that they were closer to one another compared to how they had been 100 years before. He also transferred his analysis to the sphere of politics, arguing that current economic phenomena cannot be considered without an in-depth analysis of historical facts. Additionally, he noted the ad hoc nature of economic policies, as these ignore certain long-term trends, which, in his opinion, are decisive for long-term sustainability.

De Long (1988) disputed Baumol's findings, claiming that they are not so obvious. He argued that economic processes, and in particular technology transfers, do not, in the long run, lead to complete convergence and a similar standard of living in all industrialized economies. What is more, as noted by Romer (1986), as early as in the 1980s, the gap between rich and poor countries may widen, which was later confirmed by further research (e.g. Razin 2007; Cingano, 2014). Already in the twentieth century research into economic convergence was used to assess the effectiveness of the European Union's cohesion policy. Rogut and Roszkowska (2006) examined conditional convergence in transition economies, concluding that although there was convergence in the analysed groups of economies, considerable differences continued to exist between the countries in terms of the level of economic development and long-term growth rates.

In addition, analyses of empirical data on labour productivity indicated that, in most cases, countries with a lower GDP per employee recorded a much higher growth rate in this macroeconomic variable than economies with fairly high labour productivity. In 2008, Esposti and Busoletti, analysing conditional convergence in 206 EU regions (2008), estimated the impact of cohesion policy (Objective 1) on the cohesion of these regions. They argued that this policy had a significant impact on regional convergence. Similar conclusions were reached by Eckey, Dreger, and Türck 
(2009), who argued that convergence can be accelerated in new member states. Monfort (2009) attested to the convergence of regions in his research. However, he also indicated the possibility of growth poles appearing due to the development of urban agglomerations and the drainage of development factors from surrounding areas. In 1995, 70\% of development disparities in the EU reflected disproportions between EU countries, the rest being regional disparities. This share dropped to $56 \%$ in 2005. In the EU-15, this figure decreased from 55\% in 1980 to just $14 \%$ in 2005 (Bouvet, 2005).

In turn, Petrakos and Artelaris (2009) argued that opening markets and increasing competition must lead to the emergence of regional disparities. Therefore, there is room for applying intense regional policies within the national policies of individual countries, while cohesion policies should be responsible for cohesion at the level of countries. Smętkowski and Wójcik (2008) used $\beta$ - and $\sigma$-convergence (vide Research method section) to analyse the convergence of regions, particularly in the countries of Central and Eastern Europe. They pointed to rather weak regional convergence and stressed that in most countries the intensity of regional convergence processes is low, although in smaller countries their level remains stable. Łaźniewska, Górecki, and Chmielewski (2011), who analysed regional data for Central and Eastern European countries, also stated that although convergence does occur, it is accompanied by a high variance in GDP per capita, which may be a consequence of strong agglomeration effects. Mikulić et al. (2013) analysed regional data for the NUTS 2 and NUTS 3 levels in the EU and Croatia in 2001 and 2008, indicating that national convergence is stronger than regional convergence. Jóźwik (2014), who analysed regional data, argued that the poorer regions of Central and Eastern Europe tend to develop faster than rich regions-although this principle is not universal in terms of either scope or time. Periods of economic crisis are characterized by an increasing standard deviation of the natural logarithms of regional GDP per capita, which amounts to a variation in GDP value and thus divergence.

On theoretical grounds, the effectiveness of cohesion policy is the subject of frequent disputes, mainly between the neoclassical school and advocates of the endogenous growth theory (cf. Beck and Grodzicki, 2014; Jóźwik, 2014; Kisiała, 2016). The proponents of the neoclassical growth theory, based on the Solow models, assume diminishing marginal capital productivity, which should result in diminishing disproportions between rich and poor countries in the long term. On the other hand, the advocates of the endogenous theory, in particular the so-called new economic geography (Krugman, 1991), argue that in fact the majority of factors favour divergence processes. Trade integration can result in a "core-periphery" structure, with spatial concentration of increasing returns to scale industries in the core Europe and constant returns to scale industries at the peripheries (Rodokanakis, 2006). This concerns mainly the economies of agglomeration, which occur in three forms (Gawroński, 2010) as follows: 
- Economies of scale - lowered production costs as a result of increased production levels,

- Localization economies - concentration of companies from the same industry/ sector in the same area leads to creating 'place brands',

- Urbanization economies - diversity and availability of labour force and market, as well as technical, social and administrative infrastructure.

Cities and metropolises tend to attract and concentrate investment as well as the factors of production that follow them. A consequence of this is the emergence of growth poles within these agglomerations and a shift of the development processes from peripheral areas, or even the draining of their resources (cf. Perroux, 1950; Hite, 2004; McCann and van Oort, 2009; Gaczek, 2010; Domański, 2012; MarkowskaPrzybyła, 2010; Markowska \& Strahl, 2012; Jabłoński, 2012; Kusideł, 2013). It is also emphasized that, because regions have strong links with their neighbours (both close and distant), they are much more susceptible to various shocks (e.g. cyclical). Also, the mobility of the factors of production is greater at the level of regions than countries (Beck \& Grodzicki, 2014: 16), which intensifies the divergence processes that are additionally compounded by the consequences of reducing transaction costs as well as technological changes. Finally, Magrini (2004) argued that failure to include geographical factors in the analyses, and in particular spatial factors, must lead to false conclusions.

Thus, a solution seems possible, which to a certain extent combines the two theoretical approaches, namely-that there is a real convergence between the economies of countries, although at the level of regions differences may increase. This would largely justify the legitimacy of implementing a cohesion policy at the EU level, leaving the issues relating to reducing regional disparities to national politicians. Therefore, it seems reasonable to review whether, during the European Union's last two financial perspectives (2000-2006 and 2007-2013), convergence in the economies of the EU-28 countries and regions occurred, and consequently, whether a cohesion policy implemented in the form of significant fund-transfers to economically weaker countries and regions reduced economic discrepancies in particular countries and regions.

\subsection{Research Method}

Real economic convergence assumes that economies become similar in terms of their level of development, which can be measured in various ways. The most common measures are GDP per capita and average labour productivity. This approach to convergence is called $\sigma$-convergence and refers to a reduction in the dispersion of the examined feature (e.g. GDP per capita) in a given group of economies. The second 
basic measure of convergence entails the relationship between the average rate of index growth determining the level of development and its initial value-which is connected with the concept of 'catching up' and closing the development gap between underdeveloped and developed economies. There are two types of this measure: first, unconditional (absolute) convergence, which assumes that all economies strive towards the same level of wealth within the long-term equilibrium; and second, conditional convergence, which assumes an individual path for each country, depending on the characteristics of its economy. The two concepts of convergence are interrelated: $\beta$-convergence is a necessary but an exclusive condition for the occurrence of $\sigma$-convergence (Nowak, 2007: 75).

The aim of this paper is to examine the convergence of European Union economies at the national and regional levels (NUTS2) using the measure of unconditional convergence ( $\beta$-convergence). The analysis of $\beta$-convergence was popularized by Barro and Sala-i-Martin (Barro, 1992; Sala-i-Martin, 1996; Sala-i-Martin, 1996a; Salai-Martin, 2002). However, despite criticism from some researchers (eg. Friedman, 1992; Quah, 1996; Wójcik, 2008) and some of its known limitations, $\beta$-convergence is still commonly used (Alexe, 2012; Czasonis, and Quinn, 2012; EEAG, 2010; Grzelak and Kujaczyńska, 2013; Kaitila et al., 2007; Schadler et al., 2006; Siwiński, 2012; Walczak, 2012). In order to verify the hypothesis about the occurrence of absolute $\beta$-convergence, the following equation was estimated (Matkowski \& Próchniak, 2013):

$$
\frac{1}{T} \ln \frac{y_{T}}{y_{0}}=\alpha_{0}+\alpha_{1} \ln y_{0}+\varepsilon_{t}
$$

Linear regression was used for the estimation of the equation, which makes it possible to estimate the conditional value of the expected explanatory variable for the specific values of the independent variables. The dependent variable was the average rate of growth of real GDP per capita in the period between $\mathrm{T}$ and 0 ; the independent variable was the logarithm of the initial value of GDP per capita; and $\varepsilon_{t}$ was the random component. A negative and statistically significant value of the $\alpha_{1}$ parameter signifies the existence of $\beta$-convergence. If that is the case, the value of the $\beta$ coefficient, which measures the convergence rate, can be calculated using the following formula:

$$
\beta=\frac{-1}{T} \ln \left(1+\alpha_{1} T\right)
$$

The $\beta$ parameter denotes the average rate of convergence/divergence over each period, expressed as a percentage. The higher the value of the parameter, the faster the differences disappear. Once the value of the $\beta$ coefficient is known, it is possible to calculate the half-life coefficient, referred to as the half-convergence period and described by the formula $h l=\ln (2) / \beta$. This coefficient shows how many years it takes 
to reduce the differences in the set of observations by half. To prove that convergence occurs as a result of the intervention of the cohesion policy, Pearson Correlation has been calculated between cohesion policy intervention (CF, ERDF and ESF) and both real GDP per capita and GDP per capita based on PPS.

\subsection{Results}

Estimation of the regression model was performed in several variants. The first differentiating criterion was the level of data aggregation: the parameters were estimated separately for the 28 current EU member states and for the 276 regions of the NUTS2 level (The Nomenclature of Territorial Units for Statistics 2013). The next criterion was the exchange rate: the parameters for nominal GDP per capita were estimated then converted to real terms using the GDP deflator at the level of prices for the year 2000; and in the second case, GDP per capita based on purchasing power standards (PPS) was used. Analysing purchasing power parity better reflects the nature of real economic processes as it takes into account the purchasing power of the population of a given country. In addition, different periods corresponding to specific financial frameworks were distinguished (using the $n+2$ rule): two EU financial frameworks together - the years 2000-2013 (Table 1); the 2000-2006 framework (Table 2); and the 2007-2013 framework (Table 3). The addition of two years to each framework is justified on the one hand, because of the adopted settlement period of investment projects, and on the other hand, due to the period of transmitting the effects of economic policy to the real sphere. As a result, several models have been estimated, which are presented below in Table 1.

The results presented in Table 1 indicate the occurrence of economic convergence for the analysed units in each variant, excluding "club convergence"-EU15 and EU13 (the values of the convergence coefficient are in each case negative). The convergence process, in terms of purchasing power parity, occurs much faster than if the current exchange rate is taken into account. It is also confirmed that convergence at the level of countries, in each approach occurs faster than at the level of regions. All the observations are statistically significant (for EU-28 countries and regions), and the model explains approximately $45 \%$ of the variance for the model relating to the regions of EU countries, as well as about 2/3 of the variance for the model relating to the EU countries themselves. The Durbin-Watson test indicates a negative autocorrelation of the random component. Excluding observations relating to Luxembourg and Ireland, which showed the greatest deviation from the trend, increased the fit of the model to $\mathrm{R}^{2}=0.830$ (PPS). Similarly, excluding the three most divergent observations from the model, estimated at the regional level (Bucuresti-Ilfov, Bratislava Region, Inner London-West), increased the degree of fit to $\mathrm{R}^{2}=0.507$ (PPS). Additional calculations 
Table 1: Results of the estimation of the absolute $\beta$-convergence regression equation in EU countries between the years 2000-2015.

\begin{tabular}{|c|c|c|c|c|c|c|c|c|}
\hline \multirow[t]{2}{*}{ Regression model } & \multicolumn{2}{|c|}{ Absolute term } & \multicolumn{2}{|c|}{$\begin{array}{l}\text { Convergence } \\
\text { coefficient }\end{array}$} & \multirow[t]{2}{*}{$\mathbf{R}^{2}$} & \multirow[t]{2}{*}{$\beta$} & \multirow[t]{2}{*}{$\mathrm{hl}$} & \multirow{2}{*}{$\begin{array}{l}\text { Durbin- } \\
\text { Watson } \\
\text { statistic } \\
\end{array}$} \\
\hline & $\alpha_{0}$ & $\mathrm{p}$-value & $\alpha_{1}$ & $\mathrm{p}$-value & & & & \\
\hline NUTS2 regions (PPS) & 3.404 & 0.000 & -0.309 & 0.000 & 0.450 & $2.46 \%$ & 28.130 & 0.845 \\
\hline $\begin{array}{l}\text { NUTS2 regions (current } \\
\text { exchange rate) }\end{array}$ & 1.754 & 0.000 & -0.164 & 0.000 & 0.443 & $1.19 \%$ & 58.044 & 0.695 \\
\hline EU-28 countries (PPS) & 4.498 & 0.000 & -0.410 & 0.000 & 0.657 & $3.52 \%$ & 19.705 & 1.740 \\
\hline $\begin{array}{l}\text { EU-28 countries (current } \\
\text { exchange rate) }\end{array}$ & 2.229 & 0.000 & -0.207 & 0.000 & 0.626 & $1.55 \%$ & 44.829 & 1.758 \\
\hline $\begin{array}{l}\text { NUTS2 Regions EU-15 } \\
\text { (PPS) }\end{array}$ & 0.378 & 0.000 & -0.008 & 0.000 & 0.004 & $0.05 \%$ & 1294.445 & 0.847 \\
\hline $\begin{array}{l}\text { NUTS2 Regions EU-13 } \\
\text { (PPS) }\end{array}$ & 3.136 & 0.000 & -0.265 & 0.000 & 0.273 & $2.05 \%$ & 33.770 & 1.389 \\
\hline $\begin{array}{l}\text { NUTS2 Regions EU-15 } \\
\text { (current exchange rate) }\end{array}$ & 0.544 & 0.007 & +0.064 & 0.002 & 0.004 & - & - & 0.924 \\
\hline $\begin{array}{l}\text { NUTS2 Regions EU-13 } \\
\text { (current exchange rate) }\end{array}$ & 1.472 & 0.000 & -0.120 & 0.001 & 0.160 & $0.85 \%$ & 81.334 & 1.240 \\
\hline EU-15 countries (PPS) & -2.103 & 0.110 & +0.242 & 0.067 & 0.176 & - & - & 1.958 \\
\hline EU-13 countries (PPS) & 6.339 & 0.000 & -0.609 & 0.000 & 0.827 & $6.26 \%$ & 11.072 & 2.078 \\
\hline $\begin{array}{l}\text { EU-15 countries (current } \\
\text { exchange rate) }\end{array}$ & -1.417 & 0.104 & +0.152 & 0.081 & 0.156 & - & - & 1.822 \\
\hline $\begin{array}{l}\text { EU-13 countries (current } \\
\text { exchange rate) }\end{array}$ & 2.931 & 0.000 & -0.288 & 0.001 & 0.646 & $2.26 \%$ & 30.609 & 2.053 \\
\hline
\end{tabular}

Source: Own compilation based on Eurostat data

for the so-called "club convergence", separating observations between the "old" (core EU-15) and "new" (EU-13) European Union countries were also done, adopting, as a turning point, the year 2004. 2004 in turn, marked the entry of 10 new countries into the EU with three more countries joining in subsequent years ${ }^{2}$. The results indicate a much greater fit for the country regression model of the new member states $\left(R^{2}=0.878\right.$ vs. $\mathrm{R}^{2}=0.117$ for GDP based on PPS in the years 2000-2015).

Moreover, in the case of the "old" (core) EU countries, divergence in economic development can be observed as evidenced by the positive value of the $\alpha_{1}$ coefficient.

2 The three countries have not used the structural funds on a full scale, which has an impact on the analysis as well 
This confirms the results of earlier research, which showed that convergence occurs at a higher rate in smaller and less-economically developed countries. However, it must be noted that in most cases the results of the EU-15 analysis were statistically insignificant ( $p$-value >0.05). In the case of country-level analysis for EU-15 and EU-13, we have a low sample size, which means that the results of regression analysis should be followed with caution. The results are similar to those presented in Table 2, where the period of the 2000-2008 financial perspective has been analysed Although, in this case, the value of the $\beta$ coefficient indicates a faster catch-up rate for almost each of the analysed cases. Also, the fit of the model is particularly high, especially at the level of EU countries.

Table 2: Results for the estimation of the absolute $\beta$-convergence regression equation in EU countries in the years 2000-2008.

\begin{tabular}{|c|c|c|c|c|c|c|c|c|}
\hline \multirow[t]{2}{*}{ Regression model } & \multicolumn{2}{|c|}{ Absolute term } & \multicolumn{2}{|c|}{$\begin{array}{l}\begin{array}{l}\text { Convergence } \\
\text { coefficient }\end{array} \\
\end{array}$} & \multirow[t]{2}{*}{$\mathbf{R}^{2}$} & \multirow[t]{2}{*}{$\beta$} & \multirow[t]{2}{*}{$\mathrm{hl}$} & \multirow{2}{*}{$\begin{array}{l}\text { Durbin- } \\
\text { Watson } \\
\text { statistic }\end{array}$} \\
\hline & $\overline{\alpha_{0}}$ & p-value & $\alpha_{1}$ & $p$-value & & & & \\
\hline NUTS2 regions (PPS) & 2.589 & 0.000 & -0.234 & 0.000 & 0.493 & $3.33 \%$ & 20.802 & 1.062 \\
\hline $\begin{array}{l}\text { NUTS2 regions (current } \\
\text { exchange rate) }\end{array}$ & 1.464 & 0.000 & -0.134 & 0.000 & 0.567 & $1.80 \%$ & 38.543 & 1.033 \\
\hline EU-28 countries (PPS) & 3.664 & 0.000 & -0.337 & 0.000 & 0.772 & $5.14 \%$ & 13.493 & 1.675 \\
\hline $\begin{array}{l}\text { EU- } 28 \text { countries (current } \\
\text { exchange rate) }\end{array}$ & 1.901 & 0.000 & -0.175 & 0.000 & 0.776 & $2.40 \%$ & 28.825 & 1.170 \\
\hline $\begin{array}{l}\text { NUTS2 Regions EU-15 } \\
\text { (PPS) }\end{array}$ & 1.048 & 0.000 & -0.081 & 0.000 & 0.097 & $1.06 \%$ & 65.647 & 0.968 \\
\hline $\begin{array}{l}\text { NUTS2 Regions EU-13 } \\
\text { (PPS) }\end{array}$ & 2.272 & 0.000 & -0.192 & 0.001 & 0.173 & $2.66 \%$ & 26.010 & 1.040 \\
\hline $\begin{array}{l}\text { NUTS2 Regions EU-15 } \\
\text { (current exchange rate) }\end{array}$ & 0.537 & 0.000 & -0.42 & 0.002 & 0.040 & $6.81 \%$ & 10.180 & 0.989 \\
\hline $\begin{array}{l}\text { NUTS2 Regions EU-13 } \\
\text { (current exchange rate) }\end{array}$ & 1.184 & 0.000 & -0.096 & 0.002 & 0.148 & $1.26 \%$ & 54.943 & 1.190 \\
\hline EU-15 countries (PPS) & 0.002 & 0.998 & +0.026 & 0.690 & 0.063 & - & - & 1.715 \\
\hline EU-13 countries (PPS) & 0.110 & 0.800 & +0.002 & 0.966 & 0.077 & - & - & 1.708 \\
\hline $\begin{array}{l}\text { EU- } 15 \text { countries (current } \\
\text { exchange rate) }\end{array}$ & 3.821 & 0.023 & -1.520 & 0.000 & 0.885 & - & - & 1.428 \\
\hline $\begin{array}{l}\text { EU-13 countries (current } \\
\text { exchange rate) }\end{array}$ & 2.277 & 0.000 & -0.218 & 0.000 & 0.663 & $3.07 \%$ & 22.590 & 1.572 \\
\hline
\end{tabular}

Source: Own compilation based on Eurostat data 
The next Table presents results of the analysis for the 2007-2013 financial perspective.

Table 3: Results for the estimation of the absolute $\beta$-convergence regression equation in EU countries in the years 2007-2015.

\begin{tabular}{|c|c|c|c|c|c|c|c|c|}
\hline \multirow[t]{2}{*}{ Regression model } & \multicolumn{2}{|c|}{ Absolute term } & \multicolumn{2}{|c|}{$\begin{array}{l}\text { Convergence } \\
\text { coefficient }\end{array}$} & \multirow[t]{2}{*}{$\mathbf{R}^{2}$} & \multirow[t]{2}{*}{$\beta$} & \multirow[t]{2}{*}{ hl } & \multirow{2}{*}{$\begin{array}{l}\text { Durbin- } \\
\text { Watson } \\
\text { statistic }\end{array}$} \\
\hline & $\alpha_{0}$ & $\mathrm{p}$-value & $\alpha_{1}$ & p-value & & & & \\
\hline NUTS2 regions (PPS) & 1.372 & 0.000 & -0.127 & 0.000 & 0.152 & $1.70 \%$ & 40.827 & 0.522 \\
\hline $\begin{array}{l}\text { NUTS2 regions (current } \\
\text { exchange rate) }\end{array}$ & 0.536 & 0.000 & -0.540 & 0.000 & 0.118 & $9.71 \%$ & 7.141 & 0.516 \\
\hline EU-28 countries (PPS) & 1.705 & 0.007 & -0.156 & 0.011 & 0.221 & $2.12 \%$ & 32.695 & 2.002 \\
\hline $\begin{array}{l}\text { EU- } 28 \text { countries (current } \\
\text { exchange rate) }\end{array}$ & 0.619 & 0.023 & -0.061 & 0.029 & 0.171 & $0.79 \%$ & 88.103 & 2.389 \\
\hline $\begin{array}{l}\text { NUTS2 Regions EU-15 } \\
\text { (PPS) }\end{array}$ & -0.609 & 0.015 & +0.065 & 0.008 & 0.027 & - & - & 0.540 \\
\hline $\begin{array}{l}\text { NUTS2 Regions EU-13 } \\
\text { (PPS) }\end{array}$ & 1.405 & 0.000 & -0.121 & 0.001 & 0.173 & $1.61 \%$ & 42.966 & 1.019 \\
\hline $\begin{array}{l}\text { NUTS2 Regions EU-15 } \\
\text { (current exchange rate) }\end{array}$ & -1.056 & 0.000 & +0.102 & 0.000 & 0.142 & - & - & 0.742 \\
\hline $\begin{array}{l}\text { NUTS2 Regions EU-13 } \\
\text { (current exchange rate) }\end{array}$ & 0.527 & 0.010 & -0.047 & 0.043 & 0.056 & $0.60 \%$ & 115.188 & 0.753 \\
\hline EU-15 countries (PPS) & -1.781 & 0.114 & +0.179 & 0.100 & 0.132 & - & - & 1.845 \\
\hline EU-13 countries (PPS) & -1.278 & 0.103 & +0.123 & 0.107 & 0.125 & - & - & 2.496 \\
\hline $\begin{array}{l}\text { EU-15 countries (current } \\
\text { exchange rate) }\end{array}$ & 3.942 & 0.003 & -0.384 & 0.004 & 0.547 & $6.06 \%$ & 11.445 & 1.304 \\
\hline $\begin{array}{l}\text { EU-13 countries (current } \\
\text { exchange rate) }\end{array}$ & 1.157 & 0.041 & -0.121 & 0.054 & 0.234 & $1.61 \%$ & 42.996 & 1.206 \\
\hline
\end{tabular}

Source: Own compilation based on Eurostat data

The values of the $\alpha_{1}$ convergence coefficient are negative. As such, also in this case, they indicate gradual convergence of the analysed units. However, it is worth noting the fit of the model analysed for this period is much lower than in the case of the previous financial framework. The results are still statistically significant (at EU-28 level), but the distribution of residuals indicates the presence of a significant disturbance in the model. One reason for this may be the repercussions from the 2008 financial crisis, which caused considerable economic perturbations, affecting the real economic situation of individual countries in different ways. On one hand, there is 
Poland, which suffered relatively mild consequences as a result of the crisis, but was also quick to recover. On the other hand, there are countries such as Greece, Ireland, Spain, Portugal and Italy (the so called PIIGS group), which severely experienced the effects of the crisis and fell into substantial debt; as well as countries such as Slovakia and the Czech Republic, whose economies are based on exports for which the crisis meant a significant decline in GDP; and countries such as Latvia, which resorted to "internal devaluation" in order to regain long-term competitiveness, even though, in the short term, this resulted in a significant deterioration in the real standard of living of its population. To demonstrate the relation between cohesion policy intervention and the level of GDP of EU Countries and regions, the Pearson Correlation has been calculated separately for every country and region. Average rates are presented in Tables 4 and 5.

Table 4: Results for the estimation of average correlation between cohesion policy intervention and GDP per capita measures in EU Countries in the years 2000-2015.

\begin{tabular}{lll}
\hline & $\begin{array}{l}\text { Cohesion policy/real GDP } \\
\text { per capita }\end{array}$ & $\begin{array}{l}\text { Cohesion policy/ GDP per capita } \\
\text { based on PPS }\end{array}$ \\
\hline All Countries & 0.355 & 0.412 \\
“Old" Core Members (EU-15) & 0.103 & 0.107 \\
$\begin{array}{l}\text { “New” Member States (EU-10, } \\
\text { joined in 2004) }\end{array}$ & 0.654 & 0.766 \\
“New” Member States (EU-13) & 0.646 & 0.763 \\
\hline
\end{tabular}

Source: Own compilation based on cohesion data

Table 5: Results for the estimation of average correlation between cohesion policy intervention and GDP per capita measures in EU Regions (NUST2) in the years 2000-2015.

\begin{tabular}{lll}
\hline & $\begin{array}{l}\text { Cohesion policy/real GDP } \\
\text { per capita }\end{array}$ & $\begin{array}{l}\text { Cohesion policy/ GDP per capita } \\
\text { based on PPS }\end{array}$ \\
\hline All Regions & 0.285 & 0.274 \\
"Old" Core Members Regions (EU-15) & 0.168 & 0.131 \\
“New" Member States Regions (EU-10, & 0.735 & 0.820 \\
joined in 2004) & & 0.813 \\
“New" Member States Regions (EU-13) & 0.726 & \\
\hline
\end{tabular}

Source: Own compilation based on cohesion data 
Taking all EU countries and regions into account, there is a weak correlation between cohesion policy intervention and GDP measures, which corresponds with conclusions of the report on Data Review and Mapping of Cohesion Policy Implementation and Performance (Gorzelak et. al, 2017). However, limiting calculations for the countries and regions that do receive significant structural and cohesion funds (EU-13, countries that joined after 2004), the correlation is quite significant: higher for GDP based on PPP, and also higher on the regional level. Exceptionally high correlation has been noticed in the case of Poland, the current largest beneficiary of cohesion assistance, respectively 0.903 and 0.902 for countries, and 0.836 and 0.834 average for regions.

\subsection{Conclusion}

In light of research results, it can be concluded that inequalities in the level of economic development were decreasing during the entire period between the years 2000-2015, as well as in the specific periods corresponding to EU financial frameworks; both occurring at the level of EU-28 countries and at the level of NUTS2 regions measured for EU-28. The research also confirms that convergence is more effective in smaller and less developed economies, which are the primary recipients of structural aid. One possible explanation is that the cohesion policy was effective in terms of the objectives it was designed to achieve, whereby correlation rates confirmed the possibility for "new” Member States.

Nevertheless, the pace of economic convergence, at the level of both regions and countries, was substantially different, depending on the methodology used; although, in general, it can be considered weak or, at best, moderate. When considering GDP per capita, based on purchasing power parity, the catch-up time was much shorter than when using data calculated on the basis of the current exchange rate. The regression models calculated for the NUTS2 regions (EU-28) show a much lower level of fit, although they still remain statistically significant. This may indicate that a cohesion policy is considerably more effective on a macro scale than at a regional level. The lower rate of regional convergence can certainly be attributed to agglomeration economies, the emergence of growth poles, and the phenomena analysed within the scope of economic geography-or the integration of markets, globalization, technology transfer etc. Even so, further analysis would be necessary to confirm this assertion.

The financial crisis of 2008 and the ensuing double recession in 2008 and 2011 significantly distorted the models' predictions, which can be clearly seen in the decreasing fit of the models estimated for the period 2007-2015. As indicated by the 7th report on economic, social and territorial cohesion (European Commission, 2017) and empirical studies (e.g. Jóźwik 2014), long-term disproportions in GDP per capita increased during this period and started to decrease at the end of 2014, when the EU economy entered a phase of strong recovery. The heteroscedasticity of the random 
component in most of the analysed cases indicates the need for further analysis in order to improve the model fit and take into account other factors. As so, conditional convergence merits consideration (c.f. Rogut and Roszkowska, 2006), which takes into account a number of other factors affecting the level of long-term equilibrium. For example, savings behaviour, migration, birth rate, access to technology, government economic policies and their effects, to list but a few. In further research, it may also be worth examining spatial aspects in order to determine the impact on economic results of operating in a specific location and a specific community. "Club convergence" leads us to less obvious conclusions: the convergence in the new member states is faster; in the case of the "old" EU countries we even notice divergence, but the results are not conclusive.

Recommendations from the $7^{\text {th }}$ report on economic, social and territorial cohesion on directions for EU cohesion policy for the following years seem to be accurate (European Commission, 2017). A large portion of funds has been invested in infrastructure in new Member States. Now it is time, to focus on lessinfrastructural areas, where the highest EU value-added can be achieved, like social inclusion, healthcare, climate change, energy issues, employment skills, research and innovation. The cohesion can be boosted by further reforms on improving institutional quality, government and administrative capacity, which is indirectly linked to cohesion policy tools. Only by combining high absorption of structural funds with constantly improving governance and administrative capacity, supported with growing contribution of private and national funds' investments focused on high value-added areas, can a desired effect and ongoing convergence be achieved.

\section{References}

Alexe I. (2012), How does Economic Crisis Change the Landscape of Real Convergence for Central and Eastern Europe? Romanian Journal of Fiscal Policy, no. 3.

Andrew B.G., Jr. (2001), Convergence in State per capita Personal Income, 1950-99. - Survey of Current Business.

Barro R.J., Sala \& Martin X. (2003), Economic Growth, New York: McGraw-Hill, ed. 2.

Barro, R. (2000), Inequality and Growth in a Panel of Countries, Journal of Economic Growth, 5.

Baumol W.J. (1986), Productivity Growth, Convergence, and Welfare: What the Long-Run Data Show, The American Economic Review, Vol. 76, No. 5, pp. 1072-1085.

Beck K., Grodzicki K. (2014), Konwergencja realna i synchronizacja cykli koniunkturalnych w Unii Europejskiej (Real convergence and synchronization of business cycles in the European Union), Warszawa: Wydawnictwo Naukowe SCHOLAR.

Bouvet F. (2005), European Union Regional Policy: allocation determinants and effects on regional economic growth, mimeo.

Cingano F. (2014), Trends in Income Inequality and its Impact on Economic Growth", OECD Social, Employment and Migration Working Papers, No. 163, OECD Publishing. http://dx.doi. org/10.1787/5jxrjncwxv6j-en.

Cohesion data obtained from https://cohesiondata.ec.europa.eu/EU-Level/Historic-EU-paymentsregionalised-and-modelled/tc55-7ysv accessed on August 2018. 
Czasonis M., Quinn M.A. (2012), Income Convergence in Europe: Catching Up or Falling Behind? Acta Oeconomica, no. 62(2).

Domański R. (2012), Ewolucyjna gospodarka przestrzenna, (Evolutionary spatial economy), Poznan: ydawnictwo Uniwersytetu Ekonomicznego w Poznaniu.

Eckey H., Dreger Ch., Türck M. (2009), Regional convergence in the enlarged European Union, Applied Economics Letters, Vol. 16, Issue 18, p. 1806.

Esposti R. Bussoletti S. (2008), Impact of Objective 1 Funds on Regional Growth Convergence in the European Union: A Panel-data Approach, Regional Studies, vol. 42, issue 2, pp. 159-173.

Eurostat data set https://ec.europa.eu/eurostat/data/database, access on February 2018.

Friedman M. (1992), “Do old fallacies ever die?”, Journal of Economic Literature, t. 30.

Gaczek W. (2010), Metropolia, jako źródło przewagi konkurencyjnej gospodarki regionu (Metropolis, as a source of competitive advantage of the region's economy), Acta Universitatis Lodziensis, Folia Oeconomica 246.

Gawronski H. (2010), Zarządzanie strategiczne w samorządach lokalnych, (Strategic management in local governments), Wolters Kluwer Polska Sp. z o.o..

Gorzelak G., Hryniewicz J., Kozak M., Płoszaj A., Rok J., Smętkowski M. (2017), Data review and mapping of Cohesion Policy Implementation and Performance (Report), Cohesify Research Paper, 7, Centre for Euroepan Regional and Local Studies (EUROREG), University of Warsaw.

Grzelak A., Kujaczyńska M. (2013), Real Convergence of the European Union Members States Evaluation Attempt, Management, no. 7.

Jabłoński Ł.(2012), Kapitał ludzki a konwergencja gospodarcza, (Human capital and economic cnvergence), Warszawa: C.H. Beck.

Jóźwik B. (2014), Konwergencja gospodarcza w regionach państw członkowskich Unii Europejskiej z Europy Środkowo-Wschodniej, (Economic convergence in the regions of the European Union member states from Central and Eastern Europe), Roczniki Ekonomii I Zarządzania, Tom 6 (42), no 1.

Kaitila V., Alho K.E., Nikula N. (2007), Growth Prospects of Emerging Market Economies in Europe - How Fast Will They Catch up with the Old West?, Discussion Paper, no. 115, Helsinki: The Research Institute of the Finnish Economy.

Kisiała W. (2016), Inequalities changes in the level of economic development across poviat units in Poland - convergence or divergence? Research Papers of Wroctaw University of Economics, no 418.

European Commission, Seventh Report on Economic, Social and Territorial Cohesion, My Region, My Europe, Our Future, Lewis Dijkstra, European Commission, Directorate-General for Regional and Urban Policy, Bruksela, 2017http://ec.europa.eu/regional_policy/sources/docoffic/official/ reports/cohesion7/7cr_pl.pdf access on 15022018.

Hite A.B. (2004), Natural Resource growth poles and frontier urbanization In Latin America, Studies in Comparative International Development, Fall 2004, Vol. 39, No. 3, pp. 50-75.

Krugman P. (1991), Increasing returns and Economic Geography, Journal of Political Economy, Vol. 99, no 3, pp. 483-499.

Kusideł E. (2013), Konwergencja gospodarcza w Polsce i jej znaczenie w osiąganiu celów polityki spójności (Economic convergence in Poland and its importance in achieving the objectives of cohesion policy), Łódź: Wydawnictwo Uniwersytetu tódzkiego.

Łaźniewska E., Górecki T., Chmielewski R. (2011), Konwergencja regionalna (Regional Convergence), Poznań: Wydawnictwo Uniwersytetu Ekonomicznego w Poznaniu.

Magrini S. (2004), Regional (di)convergence, [in:] J.V. Henderson, J.F. Thisse (ed.), Handbook of Regional and Urban Economics, Elsevier, t. 4.

Markowska M., Strahl D. (2012), Evaluation of the European Union Regions Convergence Regarding Innovation, Argumenta Oeconomica, 1(28), pp. 41-67. 
Markowska-Przybyła U. (2010), Konwergencja regionalna w Polsce w latach 1999-2007 (Regional convergence in Poland in 1999-2007), Gospodarka Narodowa, no 11-12, pp. 85-110.

Martin P. (2005), The geography of inequalities in Europe, Swedish Economic Policy Review, Vol. 12, p. 83.

Matkowski Z., Próchniak M. (2013), Konwergencja poziomów dochodu (Convergence of income levels), [in:] Weresa M. (ed.), Polska. Raport o konkurencyjności 2013 (Poland. The Competitiveness Report), Warszawa: Instytut Gospodarki Światowej, Szkoła Główna Handlowa.

Matkowski Z., Próchniak M., Rapacki R. (2014), Scenariusze realnej konwergencji w Unii Europejskiej - kraje EŚW a UE-15 (Scenarios of real convergence in the European Union - CEE and EU-15 countries), Warszawa: IX Kongres Ekonomistów Polskich, Szkoła Głowna Handlowa.

McCann P., and van Oort F. (2009), Theories of agglomeration and regional economic growth: a historical review [in:] Capello R., Nijkamp P, Handbook of regional growth and development theories, Cheltenham, Northampton: Edward Elgar Publishing Limited, .

Mikulić, D., Lovrinčević, Ž., \& Nagyszombaty, A.G. (2013), Regional convergence in the European Union, New Member States and Croatia, South East European Journal of Economics and Business, 8(1), 7-19.

Monfort Ph. (2009), Regional Convergence. Growth and Interpersonal Inequalities across the EU, Working Paper, Directorate General Regional Policy, European Commission.

Nowak W. (2007), Konwergencja w modelach endogenicznego wzrostu gospodarczego (Convergence in models of endogenous economic growth), Wroctaw: Kolonia Sp. z o.o..

Perroux F.(1950), Economic Space: Theory and Applications, The Quarterly Journal of Economics, Vol. 64, no 1, pp. 89-104.

Petrakos G., Artelaris P. (2009), European Regional Convergence Revisited: A Weighted Least Squares Approach Growth \& Change, Vol. 40, No. 2, p. 327.

Quah D. (1996), Convergence empirics across economies with (some) capital mobility, Journal of Economic Growth, t. 1 (1).

Razin A. (2007), Review of Elhanan Helpman's book: “The mystery of Economic Growth”, Israel Economic Review, Vol. 5 no.2, pp.129-139.

Rodokonakis S. (2006), How effective are the regional Policies of the Convergence in the EU?, European Research Studies, Volume IX, Issue (3-4).

Rogut A., Roszkowska S. (2006), Konwergencja warunkowa w krajach transformacji (Conditional Convergence in transition countries), Gospodarka Narodowa no 9.

Romer P. (1986(, Increasing Returns and Long Run Growth, Journal of Political Economy, 94, 1002-37.

Sala-i-Martin X. (1996), Regional cohesion: Evidence and theories of regional growth and convergence, European Economic Review, t. 40.

Sala-i-Martin X. (1996a), The classical approach to convergence analysis, Economic Journal, t. 106.

Sala-i-Martin X. (2002), Fifteen years of new growth economics: What have we learned? Journal Economía Chilena, t. 5 (2).

Schadler S., Mody A., Abiad A., Leigh D.,. (2006), Growth in the Central and Eastern European Countries of the European Union, IMF Occasional Paper, no. 252, Washington.

Siwiński W. (2009), Wzrost gospodarczy Polski i krajów Europy Środkowo-Wschodniej: czy możliwa jest trwała konwergencja dochodowa z Europą Zachodnią? (The economic growth of Poland and the countries of Central and Eastern Europe: whether permanent income convergence with Western Europe is possible?), [in:] Liberda Z.B., Konwergencja gospodarza Polski (Economic Convergence in Poland), Warszawa: PTE.

Smętkowski M., Wójcik P. (2008), Regiony w Europie Środkowo-Wschodniej: tendencje i czynniki rozwojowe (Regions in Central and Eastern Europe: Trends and Growth Factors), Warszawa: Centrum Europejskich Studiów Regionalnych i Lokalnych Uniwersytet Warszawski.

Tsionas, E. G. (2000), Regional growth and convergence: evidence from the United States, Regional Studies, 34, pp 231-238. 
Walczak E. (2012), Czynniki wzrostu gospodarczego w krajach Unii Europejskiej (Factors of economic growth in the countries of the European Union), "Wiadomości statystyczne, 2012, no 4.

Wójcik P. (2008), Dywergencja czy konwergencja: dynamika rozwoju polskich regionów (Divergence or convergence: the dynamics of the development of Polish regions), Studia Regionalne i Lokalne, no 2(32). 